\title{
Barrett's Esophagus in Romania: what do we know?
}

\author{
CLAUDIA PILOIU, DAN L. DUMITRASCU \\ $2^{\text {nd }}$ Dept. of Internal Medicine, Iuliu Hatieganu University of Medicine and Pharmacy, Cluj-Napoca, Romania
}

\begin{abstract}
Background and aims. The incidence of Barrett's Esophagus (BE) is increasing worldwide, thus diagnosis is becoming a major key of interest in preventing esophageal adenocarcinoma. Because the status of BE in Romania is unclear, we performed a narrative review to comprehensively evaluate all published articles on BE from Romania.

Methods. We conducted a systematic literature search of PubMed data base and of all Romanian medical journals. The abstracts and the titles of the identified studies were reviewed to exclude the studies that did not answer the search question. In addition we performed a manual search to identify articles on this topic published earlier in local journals or not indexed on internet.

Results. A total of 17 articles were found. 8 studies and 9 reviews were identified, with a total of 8,829 participants enrolled. The results showed that the median age ranges between 54-59 years, with a predominance for male sex, the main risk factors, such as gastroesophageal reflux disease, obesity, smoking, hiatal hernia, are also present in Romania and infection with H. pylori has a protective effect. The diagnosis of Barrett's esophagus in Romania is established in agreement with international guidelines.

Conclusions. There are not many publications on BE in Romania. However the data in this country are similar to those reported in other countries. The management is carried out according to standard guidelines. Diagnosing BE relies on endoscopic techniques and classification systems. Risk factors such as gastroesophageal reflux, hiatal hernia, obesity and Helicobacter pylori are considered in Romanian articles. More studies are welcome on this matter in our country.
\end{abstract}

Key words: Barrett's esophagus, endoscopy, esophagus, gastroesophageal reflux, Romania.

\section{INTRODUCTION}

Barrett's esophagus (BE) is a premalignant condition in which the normal squamous epithelium of the distal esophagus is replaced by an intestinal metaplasia [1], [2]. The condition raises 30-50 times the risk for esophageal adenocarcinoma (EAC) development, with an annual incidence of approximately $0.5 \%$ [3], [4].

The aim of the article is to present an overview of the total published articles in Romania or by Romanian authors, describing BE. The main question is if the information included in searched studies is similar to international data. We analyzed demographic data, etiology, pathogenesis and diagnostic methods.

\section{METHODS}

A systematic literature search of PUBMED was conducted using Prisma flow chart, as shown in fig. 1. The key words used in the search included the following: "Barrett", "esophagus", "oesophagus", "Barrett esophagus", "Romania" or "Romanian".
The abstracts and the titles of the identified studies were reviewed to exclude studies that did not answer the question of interest. In order to find out more data in not indexed Romanian journals, we undertook a manual search to identify more papers (Acta Medica Marisiensis, Acta Medica Transilvanica, Chirugia (not indexed issues), HVM Bioflux, Journal of Gastrointestinal and Liver Diseases (before Romanian Journal of Gastroenterology not being indexed), Romanian Biotechnological Letters, Practica Medicala etc.). First a single researcher conducted the search in a period of six months, for multiple times. Later the manual search was independently conducted by the second investigator.

\section{RESULTS}

The search generated 30 studies. Two studies were excluded because only the abstract was identified through search (the articles were released in 1989 and 1999). BE was only mentioned, but not described, in other four articles, which were not included. Other three articles were excluded because they presented only theoretical information and surgical 
techniques. After applying the exclusion criteria, 17 studies were considered to be eligible. After evaluating all the selected articles, there were identified 7 prospective studies, one retrospective study and 9 reviews.
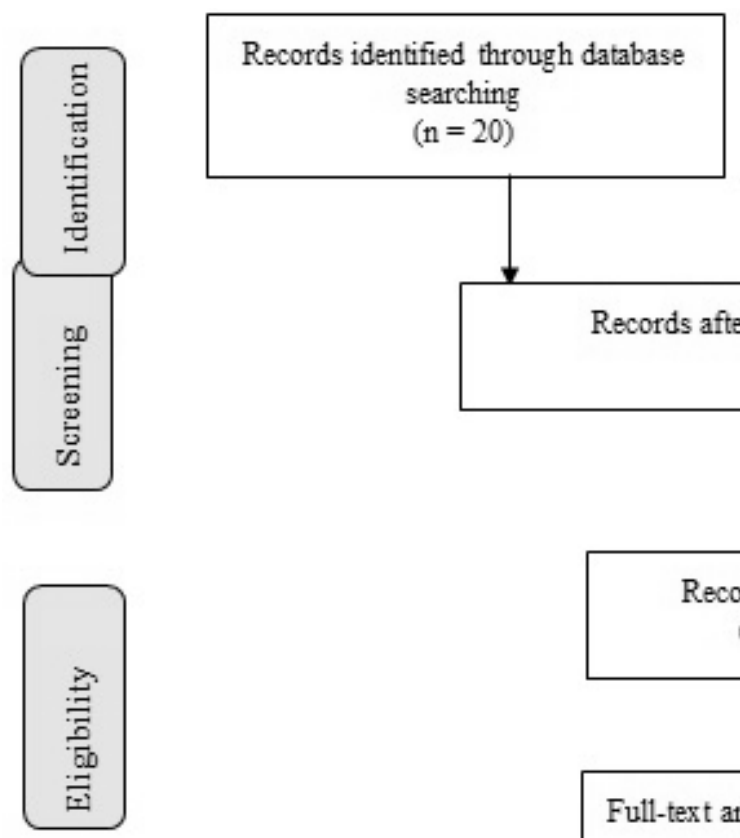

Records after duplicates removed $(n=30)$
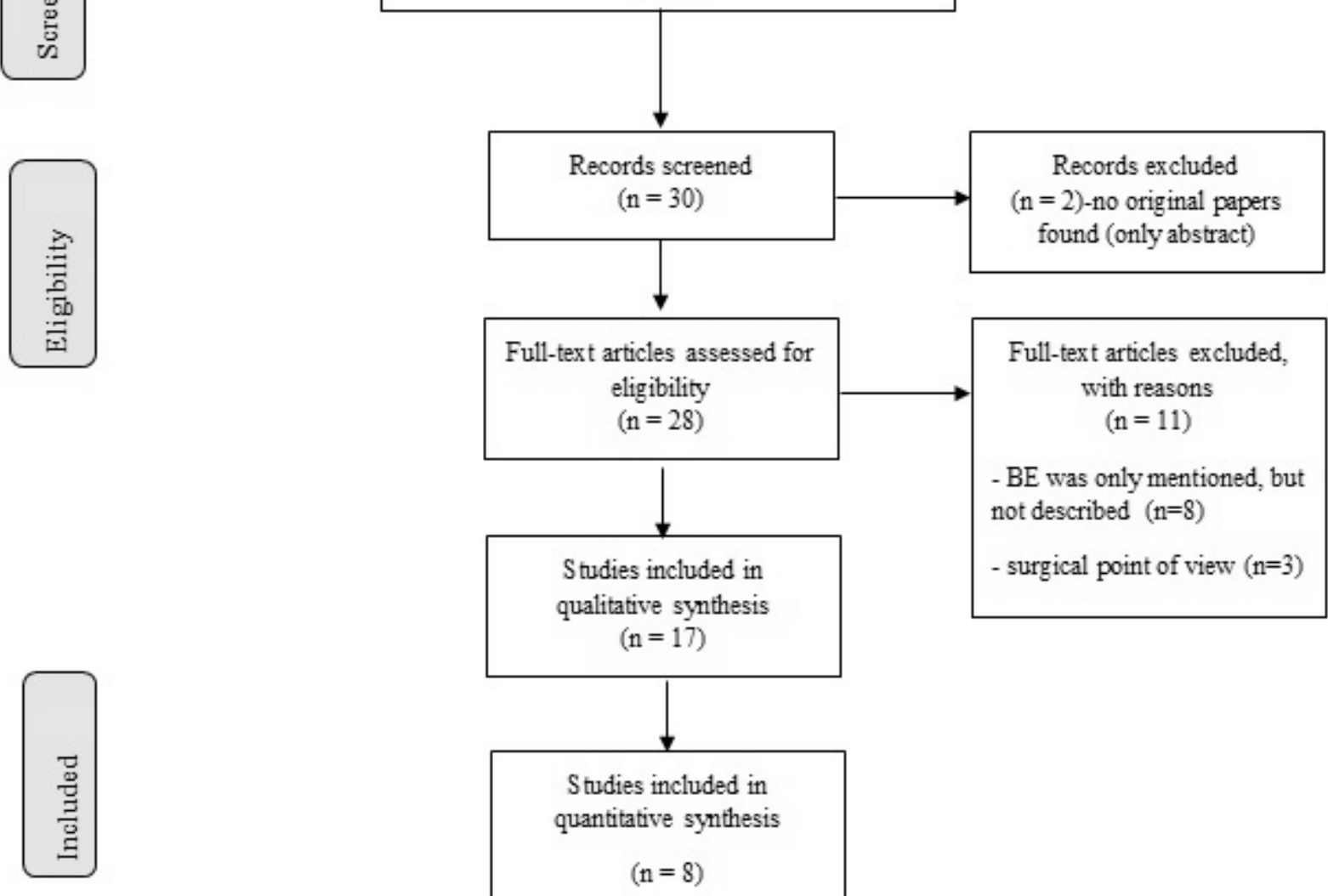

The eight original studies enrolled a total of 459 patients with $\mathrm{BE}$, from 5 cities of Romania (Bucharest, Cluj-Napoca, Craiova, Galati, Targu Mures). A number of 182 from 459 participants are included in the retrospective study.

Additional records identified through other sources $(\mathrm{n}=11)$

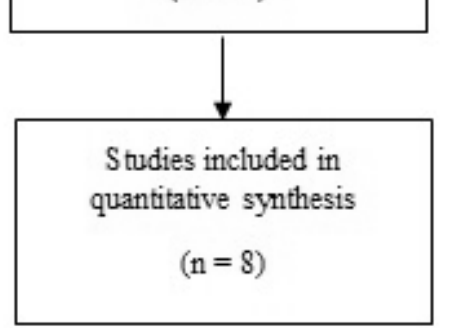

Figure 1. Prisma 2009 Flow Diagram.

In Table 1 is shown that most of the studies are prospective, with one exception (Saraci G et al. [5]) and the predominant center for patients' selection is Targu-Mures. For the recruitment of the patients, the authors are using different strategies, such as endoscopic aspects, biopsy and symptoms.

\section{Etiology and pathogenesis}

The most important pathogenic factor in the development of $\mathrm{BE}$ is the gastroesophageal reflux disease (GERD), which in its turn is a major predisposing condition for esophageal adenocarcinoma. Acid or alkaline reflux induces cell injury that finally could result in intestinal metaplasia [5]. The prevalence of $\mathrm{BE}$ rises up to $20 \%$ in patients with GERD [13] and according to Saraci G et al. [5], $30.9 \%$ of patients had esophagitis at gastroscopy, $15 \%$ Los Angeles class A and 1.7\% class D. There are several conditions that can increase the gastroesophageal reflux, as obesity, nutrition, drugs, smoking, pregnancy, hiatal hernia, surgery, because they interfere with one or more links of the antireflux physiological mechanisms [14], [15]. 
Table 1

Presentation of the types of studies included in the review, center, period of time and aspects for patient recruitment

\begin{tabular}{|l|l|l|l|}
\hline \multicolumn{1}{|c|}{ Studies included } & Type of study & \multicolumn{1}{c|}{ Center \pm period } & \multicolumn{1}{|c|}{ Recruitment } \\
\hline Saraci G et al. [5] & retrospective & $\begin{array}{l}\text { Cluj-Napoca; January } \\
1^{\text {st }}, 2005-\text { December } \\
31^{\text {st }}, 2007\end{array}$ & endoscopy records $^{\mathrm{a}}$ \\
\hline Ciobotaru O.R et al. [6] & prospective & Galati; 2005-2014 & biopsy samples $^{\mathrm{b}}$ \\
\hline Hoara P et al. [7] & prospective & $\begin{array}{l}\text { Bucharest; July- } \\
\text { December 2007 }\end{array}$ & GERD symptoms $^{\mathrm{c}}$ \\
\hline Pascarenco O et al. [8] & prospective & $\begin{array}{l}\text { Targu Mures; 2008- } \\
2010\end{array}$ & $\begin{array}{l}\text { suspected or proven BE } \\
\text { after standard upper } \\
\text { endoscopy }\end{array}$ \\
\hline Petrisor C et al. [9] & prospective & Craiova & GERD symptoms \\
\hline Pascarenco O et al. [10] & prospective & $\begin{array}{l}\text { Targu Mures } \\
\text { suspected BE after } \\
\text { standard upper } \\
\text { endoscopy }\end{array}$ \\
\hline Pascarenco O et al. [11] & prospective & $\begin{array}{l}\text { Targu Mures; January } \\
\text { 2012- June 2012 }\end{array}$ & GERD symptoms \\
\hline Pascarenco O et al. [12] & prospective & $\begin{array}{l}\text { Targu Mures; January } \\
\text { 2013- December 2014 }\end{array}$ & $\begin{array}{l}\text { endoscopic aspects of } \\
\text { BE }\end{array}$ \\
\hline
\end{tabular}

${ }^{a}$ from database were selected all patients undergoing upper digestive endoscopy.

${ }^{\mathrm{b}}$ biopsy samples included gastro-esophageal junction carcinoma and Barrett's metaplasia.

${ }^{\mathrm{c}}=$ Gastroesophageal reflux disease symptoms.

Hiatal hernia is an important risk factor for BE, $38.2 \%$ of patients included in Saraci et al. [5] study being diagnosed with this pathology during upper digestive endoscopy. The length of the metaplastic esophageal segment is increased in patients with larger hiatal defect. The existence of hiatal hernia has been positively correlated with the presence of esophagitis, but the correlation was more valid in association with obesity $(p=0.37)$. Obesity is an important risk factor involved in the development of BE. Waist circumference, body mass index (BMI), the presence of cytokines released by adipocytes, are important in developing BE [5]. In Saraci et al. [5] study, $4.1 \%$ of the patients had class I obesity, $4.2 \%$ class II and $3.1 \%$ class III. High serum concentration of leptin in men are associated with increased risk of BE. This theory is explained by the high expression of receptors of leptin in BE and disposition of adipocytes in male body [17].

Helicobacter pylori $(\mathrm{Hp})$ infection has been statistically significant associated with $\mathrm{BE}$, with a rate of $18.9 \%$ from the total number of patients, but with a low negative correlation $(p=0.02)$, according to Saraci et al. [5]. Hp may reduce gastric acidity by urease, being a protector against $\mathrm{BE}$. The high $\mathrm{Hp}$ infection prevalence in Romania might explain the lower prevalence of GERD and esophagitis, especially the severe forms like BE and esophageal adenocarcinoma [16]. Pascarenco et al. [11] described intestinal metaplasia of the cardia in comparison to BE. Intestinal metaplasia of the cardia is a common finding in elderly people and it is negatively correlated with GERD symptoms (9\%), endoscopic esophagitis $(4.5 \%)$, hiatal hernia $(11.3 \%)$ and a strong association with $\mathrm{H}$. pylori infection $(59 \%)$, cardia inflammation $(100 \%)$ and distal gastric intestinal metaplasia (70.4\%).

\section{Diagnosis}

Diagnosing $\mathrm{BE}$ in Romania requires the presence of intestinal metaplasia and it is based on all endoscopic techniques used worldwide. In Saraci $G$ et al. [5] study, $2.2 \%$ of the patients undergoing upper digestive endoscopy had BE. White light endoscopy (WLE) is described in studies in comparison with other more specific techniques, such as magnifying chromoendoscopy and narrow-band imaging.

Magnifying chromoendoscopy with methylene blue (CHR) has long been considered a good diagnostic method and it is used in two Romanian studies. A comparative study is presented in Pascarenco O et al. [10], between magnification chromoendoscopy with directed biopsies and standard endoscopy with random biopsies. The study showed $83.3 \%$ identification of specialized intestinal metaplasia during CHR vs. $65.3 \%$ performing standard endoscopy. The number of biopsies were fewer using CHR (51 vs. 71) and the number of biopsies with specialized intestinal metaplasia was higher (66.6\% vs. $38 \%)$, comparing with standard endoscopy with random biopsies. 
Narrow-band imaging (NBI) is used in two of the studies included in the systematic review. Comparing the number of biopsies per patient, the analysis showed an average of 3.04 biopsies/patient for WLE and 1.82 biopsies/patient for NBI. Fifteen $(19.2 \%)$ of the patients with intestinal metaplasia missed diagnosis in WLE group, were diagnosed with goblet cells by NBI [12].

Immunohistochemical examination is supposed to increase diagnostic accuracy in BE. In Ciobotaru et al. [6] study, is shown that the immunohistochemical expression of the proliferating factor Ki-67 was positive in $45-55 \%$ of Barrett's metaplasia cases and moderately or strong positive in $100 \%$ of the gastroesophageal junction adenocarcinomas. The overexpression of p53 was found in $63 \%$ of the patients with esophageal adenocarcinoma and 49\% of the patients with gastric cardia adenocarcinoma, but the distinction between the two adenocarcinomas should not be based on a single method, but a combination of clinical symptoms and endoscopic surveillance, with precise endoscopic biopsies, histopathological results and immunohistochemical features should be used [6].

There is no data in Romanian studies considering screening and prevention of BE. There is only one study, Hoara P et al. [7], which described the role of manometry for patients with GERD and $\mathrm{BE}$. The article is considering screening through manometry if the patients do not respond to proton pump inhibitors. The lack of response to medication is ascribed to the lower inferior esophageal sphincter dysfunction, but the study included only 24 patients.

The objectives presented in each article are included in Table 2.

Table 2

Diagnosis, symptoms and risk factors for BE

\begin{tabular}{|c|c|c|c|}
\hline Studies including in this review & Risk factors & Diagnosis & Symptoms \\
\hline Saraci G et al. [5] & $\begin{array}{l}\text { Age, sex, BMI, hiatal } \\
\text { hernia, gastric } \\
\text { surgery, Helicobacter } \\
\text { pylori, reflux } \\
\text { esophagitis, smoking }\end{array}$ & White light endoscopy & - \\
\hline Ciobotaru O. et al. [6] & T & Immunohistochemistry & $\begin{array}{l}\text {-dysphagia, } \\
\text { odynophagia, } \\
\text { chronic gastro- } \\
\text { oesophageal reflux, } \\
\text { bleeding, weight loss }\end{array}$ \\
\hline Hoara P et al. [7] & - & White light endoscopy & -GERD symptoms \\
\hline Pascarenco $\mathrm{O}$ et al. [8] & - & $\begin{array}{l}\text { White light endoscopy, } \\
\text { magnification } \\
\text { chromoendoscopy with } \\
\text { methylene blue }\end{array}$ & - \\
\hline Petrisor C et al. [9] & - & Narrow band imaging & $\begin{array}{l}\text {-dyspeptic } \\
\text { symptoms }\end{array}$ \\
\hline Pascarenco O et al. [10] & $\begin{array}{l}\text { Age, sex, BMI, hiatal } \\
\text { hernia }\end{array}$ & $\begin{array}{l}\text { White light endoscopy, } \\
\text { magnification } \\
\text { chromoendoscopy with } \\
\text { methylene blue }\end{array}$ & $\begin{array}{l}\text {-GERD symptoms, } \\
\text { esophagitis }\end{array}$ \\
\hline Pascarenco O et al. [11] & $\begin{array}{l}\text { Age, sex, hiatal } \\
\text { hernia, history of } \\
\text { cigarette smoking, use } \\
\text { of alcohol, height, } \\
\text { weight }\end{array}$ & White light endoscopy & -GERD symptoms \\
\hline Pascarenco $\mathrm{O}$ et al. [12] & - & $\begin{array}{l}\text { White light endoscopy, narrow } \\
\text { band imaging }\end{array}$ & - \\
\hline
\end{tabular}

Table 2 is summarizing the information given in results section of this study. Risk factors, diagnosis and symptoms are enumerated with examples from the articles, where they occur.

\section{Demographic data}

BE frequently affects middle aged men, with a sex ratio of 2:1 (men-women) found amongst Caucasians and unusual in African-Americans
[17]. The data included in the systematic review is presented in Table 3, describing the demographic aspects in Romania.

According to Table 3, in Romania, the median age ranges between $54-59$ years, with a predominance 
for male sex, with a slight exception in 2 studies $(\mathrm{M} / \mathrm{F}-45.8 / 54.2$ in Hoara $\mathrm{P}$ et al. [7] and sex ratio 1/1.1 in Pascarenco O et al. [11]). Saraci et al. [5], Ciobotaru O et al. [6], Hoara P et al. [7], Pascarenco O et al. [11] studies do not include only patients with $\mathrm{BE}$, as mentioned in the description of the Table 2. It is not possible to extract only the patients with BE from the articles, to create a specific demographic data table.

Table 3

Demographic data of studies on Barrett's esophagus (BE) included in the narrative review

\begin{tabular}{|l|c|c|l|l|}
\hline \multicolumn{1}{|c|}{ Studies including in this review } & \multicolumn{1}{|c|}{$\begin{array}{c}\text { Number of } \\
\text { patients }\end{array}$} & $\begin{array}{c}\text { Patients with } \\
\text { BE }\end{array}$ & \multicolumn{1}{|c|}{ Age (years) $^{\mathbf{a}}$} & \multicolumn{1}{|c|}{ Sex (M/F) $^{\mathbf{b}}$} \\
\hline Saraci G et al. [5] & 8,225 & 182 & $54.93(18-96)$ & $56.6 / 43.4$ \\
\hline Ciobotaru O. et al. [6] & 109 & 18 & $\begin{array}{l}46 \text {-benign lesions }{ }^{\text {c }} \\
65 \text {-malign lesions }\end{array}$ & $2: 1$ ratio \\
\hline Hoara P et al. [7] & 24 & 4 & 58 & $45.8 / 54.2$ \\
\hline Pascarenco O et al. [8] & 51 & 51 & $58(28-83)$ & $62.7 / 37.3$ \\
\hline Petrisor C et al. [9] & 46 & 46 & 54.5 & $91.3 / 8.7$ \\
\hline Pascarenco O et al. [10] & 50 & 50 & $58.73(29-80)-$ group 1 & $70.8 / 29.2-$ group 1 \\
\hline Pascarenco O et al. [11] & 286 & 24 & $56.54(32-84)-$ group 2 & $46.1 / 53.9-$ group 2 \\
\hline Pascarenco O et al. [12] & 84 & 84 & $57.4(26-84)$ & $1 / 1.1^{\text {d }}$ \\
\hline
\end{tabular}

Pascarenco $\mathrm{O}$ et al. have 4 different studies by the same authors.

[5] - 182 patients from 8,225 with BE.

[6] - 18 of 109 patients had BE.

[7] - 4 patients were diagnosed with BE.

[11] - from a total of 286 patients, only 24 were diagnosed with BE.

${ }^{a}$ Age is given in years as a median, with the range given in paranthesis.

${ }^{\mathrm{b}}$ Sex is expressed in percentage.

${ }^{c}$ The article does not include the total median age, the information is shown in two subgroups: the mean age for benign and for malign lesions.

${ }^{\mathrm{d}}$ The study does not contain sex data in percentage or number, only in ratio.

[10] In this study, 50 patients are divided in 2 groups: one group of 24 patients underwent magnification chromoendoscopy with directed biopsies and the second group of 26 patients followed standard endoscopy with random biopsies.

\section{DISCUSSION}

Prevalence of $\mathrm{BE}$ in general population undergoing upper digestive endoscopy for various complaints is 1\% in European studies (Italian 1.3\% and Swedish $1.6 \%$ ) and $5.6 \%$ in the United States [28] vs. $2.2 \%$ in Romania (Saraci G et al. [5]).

The main risk factors for developing BE are male gender, increased age, white race, smoking and gastro-esophageal reflux disease simptoms [18]. It is not seen a specific risk factor for the Romanian population. Some studies determined that advanced age is associated with higher rate of BE [19] and male sex is considered to be a risk factor for the disease [20]. Up to $90 \%$ of the patients with $\mathrm{BE}$ have an associated hiatal hernia, the latter being responsible, along with the other factors, for the reflux of the gastric juice in the esophagus [21]. Obesity is a risk factor for GERD and it may be a risk factor for $\mathrm{BE}$; other studies have suggested that abdominal obesity is more likely associated with an increased risk of BE than BMI [17]. $\mathrm{H}$. pylori infection is negatively correlated with $\mathrm{BE}$, as shown in Romanian articles, practically there is a lower independent probability of $25 \%$ for the patients infected with $\mathrm{Hp}$ to have $\mathrm{BE}$, compared with the patients without this infection. Hp infection could result in chronic gastritis, intestinal metaplasia and gastric cancer, yet the infection could reduce the risk ok $\mathrm{BE}$ as chronic gastritis reduces the production of gastric acid [22].

There is strong evidence suggesting that intestinal metaplasia of the cardia is the response of chronic injury of the gastric mucosa and the inflammation caused by $\mathrm{H}$. pylori, as shown in Pascarenco et al. [11] study and hiatal hernia and GERD symptoms are associated with BE [23].

A worldwide endoscopic grading system has been recommended for assessing the extent of BE. In Petrisor C et al. study [9], Prague [24] and Amsterdam [25] classification are used for modifications observed during endoscopy and two other classifications are used for detecting the mucosal and the vascular pattern. Pascarenco $\mathrm{O}$ et al. [12] identifies the importance of NBI vs. WLE, using the Sharma et al. [26] classification of mucosal and vascular patterns, Prague classification [24] and Vienna classification [27] of gastrointestinal epithelial neoplasia.

In all Romanian articles describing WLE, biopsies were taken according to Seattle protocol [28]. 
Classification systems of esophageal dysplasia, as American Society for Gastrointestinal Endoscopy classification and British Society of Gastroenterology revised Vienna classification and dysplasia subtypes are not mentioned in Romanian studies [29]. For mucosal and vascular patterns there is no international unique classification system.

In Romanian studies, Endo et al. classification [30], Amsterdam classification [25] and Sharma et al. [26] classification systems are used and the results regarding the association of the mucosal pattern with types of dysplasia are similar with international studies. In the Romanian studies the superiority of CHR and NBI vs. WLE was shown, but there is no comparison between CHR and NBI in assessment of diagnosis. Addition of p53 immunostain to histopathological assessment may improve diagnostic reproducibility of diagnosis of dysplasia and should be considered an adjunct to routine clinical diagnosis [31], as shown in Ciobotaru et al. [8].

Considering the role of manometry in the screening of the BE, there are studies showing that the presence of esophageal motor disorder is a strong independent associated factor of $\mathrm{BE}$ and that searching for motor disorders in patients suffering from GERD could be a new strategy to organize the endoscopic follow-up [32].

However we consider that the interest of Romanian gastroenterologists on Barrett's esophagus should increase, given the limited number of papers addressed to this condition.

\section{CONCLUSIONS}

In conclusion, this overview of Barrett's esophagus in Romania suggests that Romanian clinicians rely on European guidelines and international classification systems. Pathogenic factors, such as GERD, hiatal hernia, obesity, H. pylori infection are described in Romanian articles. BE frequently affects middle-aged men, as shown in this systematic review. Diagnosing BE includes endoscopic techniques such as white light endoscopy, magnifying chromoendoscopy with methylene blue, narrowband imaging and the biopsies are taken using Seattle protocol. The Romanian studies use the international classification systems. More studies on $\mathrm{BE}$ are necessary in this country, mainly on screening strategies and therapy.

Introducere şi scop. Diagnosticul esofagului Barett are o importanţă deosebită în prevenirea adenocarcinomului esofagian, deoarece incidenţa acestei patologii precanceroase este în continuă creștere. Datorită faptului că în România nu se cunoaşte statusul existenţei esofagului Barrett, am efectuat un review narativ care cuprinde toate articolele publicate în ţara noastră.

Metode. S-a efectuat o căutare sistematică în baza de date PubMed şi în revistele medicale româneşti, cu excluderea articolelor care nu au răspuns cerinţelor cheie. Au fost incluse şi articole neindexate online.

Rezultate. Dintr-un total de 17 articole care descriu esofagul Barrett in România, s-au identificat 9 review-uri şi 8 studii bazate pe pacienţi. Rezultatele au demonstrat faptul că vârsta medie a dezvoltării esofagului Barrett este de 54-59 de ani, cu o predominanţă a sexului masculin. S-a evidenţiat faptul că principalii factori de risc implicaţi sunt refluxul gastro-esofagian, obezitatea, fumatul, hernia hiatală, iar infecţia cu Helicobacter pylori are un efect protectiv. Diagnosticul esofagului Barrett în România se efectuează conform normelor internaţionale.

Concluzii. Prin efectuarea acestui review s-a demonstrat faptul că factorii de risc, diagnosticul şi tratamentul esofagului Barrett sunt în conformitate cu ghidurile internaţionale. Este necesar ca în viitor să se aducă mai multe date despre esofagul Barrett în România, deoarece numărul articolelor cercetate a fost limitat.

Correspondence to: Prof. Dr. Dan L. Dumitrascu, "Iuliu Hatieganu" University of Medicine and Pharmacy, Clinica Medicala 2, str. Clinicilor 2-4, RO-400003 Cluj-Napoca, Romania

E-mail: ddumitrascu@umfcluj.ro

Aknowledgments: Not applicable

Conflict of interest disclosure: The authors declare that there are no conflicts of interest. 


\section{REFERENCES}

1. SPECHLER SJ. Barrett's esophagus and esophageal adenocarcinoma: pathogenesis, diagnosis and therapy. Med Clin North Am 2002; 86(6):1423-45.

2. SHLAHEEN N, RANSOHOFF DF. Gastroesophageal reflux, Barrett esophagus and esophageal cancer: scientific review. Jama. 2002; 287(15):1972-1981.

3. BARR H. KENDALL C, BAZANT-HEGEMARK F, MOAYYEDI P, SHETTY G, STONE N. Endoscopic screening and surveillance for Barrett's esophagus clinical implications. Med Gen Med 2006; 8:88.

4. SHARMA P, FALK GW, WESTON AP, REKER D, JOHNSON M, SAMPLINER RE. Dysplasia and cancer in a large multicenter cohort of patients with Barrett's esophagus. Clin Gastroenterol Hepatol 2006; 4:566-572.

5. SARACI G, STEFAN C, PASCU O. Epidemiologic aspects in esophageal pathology focusing on gastroesophageal reflux disease and Barrett's esophagus. HVM Bioflux, 2011, vol. 3, issue 2.

6. CIOBOTARU OR, VOINESCU DC, CIOBOTARU OC, VOICU D, ARBUNE M. Expression of p53 and Ki-67 in distal oesophageal and gastric cardia adenocarcinomas. Romanian Biotechnologival Letters, Vol. 20, No. 5, 2015.

7. HOARA P, BIRLA R, GINDEA C, CONSTANTIN A, PANAITESCU G, IORDAN N, CONSTANTINOIU S. The role of esophageal manometry in the management of the patients with gastro-eophageal reflux disease and Barrett's esophagus. Chirurgia (Bucur). 2008,103(4):407-12.

8. PASCARENCO O, DOBRU D, BOERIU A, BRUSNIC O, GALEANU I, ONISOR D ET AL. The usefulness of magnifying chromoendoscopy with methylene blue in the detection of specialized intestinal metaplasia and dysplasia in Barrett's Esophagus - a preliminary report. AMM 2012, Vol. 58, No 3.

9. PETRISOR C.A, MICU-TUDORICA S, ENACHESCU V, CIUREA P, GHEONEA D. The role of narrow band imaging in Barrett esophagus diagnosis. Practica Medicala, Vol. VII, No 1(25), 2012.

10. PASCARENCO O, DOBRU D, BOERIU A, BRUSNIC O, ONISOR D, STOIAN M et al. The importance of magnification chromoendoscopy with methylene blue in detecting specialized intestinal metaplasia in short segment Barrett's esophagus. HVM Bioflux 4(1):40-44.

11. PASCARENCO O, BOERIU A, MOCAN S, PASCARENCO G, DRASOVEANU S, GALEANU M ET AL. Barrett's Esophagus and intestinal metaplasia of gastric cardia: prevalence, clinical, endoscopic and histological features. J Gastrointest Liver Dis. 2014, Vol. 23, No 1:19-25.

12. PASCARENCO O, COROS MF, PASCARENCO G, BOERIU A, DRASOVEAN S, ONISOR D et al. A preliminary feasibility study: narrow-band imaging targeted versus standard white light endoscopy non-targeted biopsies in a surveillance Barrett's population. Digestive and Liver dis, 2016.

13. GINDEA C, BIRLA R, HOARA P, CARAGUL A, CONSTANTINIU S. Barrett Esophagus: history, definition and etiopathogeny. Journal of Medicine and Life Vol. 7, Special Issue 3, 2014.

14. PASCU O. Boala de reflux gastroesofagian. Esenţialul în Gastroenterologie şi Hepatologie. Ed Naţional Buc 2003:4.

15. PASCU O. Tratamentul bolii de reflux gastro-esofagian. Br Med J (ed. ro) 2002; 7:308-312.

16. PASCU O, LENCU M. Barrett's Esophagus. Rom J. Gastroenterol. 2004; 13(3):219-22.

17. TANTAU M, LASZLO M, TANTA A. Barrett's Esophagus-state of the art. Chirurgia (Bucur) 2018; 113:46-60.

18. IRELAND CJ, THOMPSON SK, LAWS TA, ESTERMAN A. Risk factors for Barrett's esophagus: a scoping review. Cancer Causes Control 2016; 27(3):301-23.

19. ELOUBEIDI M.A, PROVENZALE D, Clinical and demographic predisctors of Barrett's esophagus among paients with gastroesophageal reflux disease: a multivariable analysis in veterans. J Clin Gastroenterol 2001; 33:306-309.

20. WESTHOFF B, BROTZE S, WESTON A, MCELHINNEY C, CHERIAN R, MAYO M.S, ET AL. The frequency of Barrett'sesophagus in high-risk patients with chronic GERD. Gastrointest Endosc 2005; 61(2):226-31.

21. ANDRICI J, TIO M, COX MR, ESLIK GD. Hiatal hernia and the risk of Barrett's esophagus. J Gastroenterol Hepatol. 2013; 28(3):415-31.

22. GRAHAM DY, YAMAOKA Y. H. pylori and cagA: relationships with gastric cancer, duodenal cancer and reflux esophagitis and its complications. Helicobacter 1998; 3:145-51.

23. TULASSAY Z, STOLTE M, ENGSTRAND L, BUTRUK E, MALFERHEINER P, DITE P ET AL. Twelve-month endoscopic and histological analysis following proton-pump inhibitor-based triple therapy in Helicobacter pylori-positive patients with gastric ulcers. Scand J Gastroenterol 2010; 45:1048-1058.

24. SHARMA P, DENT J, ARMSTRONG D, BERGMAN JJ, GLOSSNER L, HOSHIHARA Y ET AL. The development and validation of an endoscopic grading system for Barrett's esophagus: the Prague C\&M criteria. Gatroenterology 2006; 131(5):1392.

25. BALDAQUE SF, MARQUES M, LUNET N, THEMUDO G, GODA K, TOTH E ET AL. Endoscopic assessment and grading of Barrett's esophagus using magnification endoscopy and narrow band imaging: impact of structured learning and experience of the accuracy of the Amsterdam classification system. Scandinavian J Gastroenterol 2012; 48(2):160-167.

26. SHARMA P, BENSAL A, MARTHUR S, WANI S, CHERIAN R, MCGREGOR D ET AL. The utility of a novel narrow band imaging endoscopy system in patients with Barrett's esophagus. Gastrintest Endosc 2006; 64:167-75.

27. SCHEMPLER R, RIDDELL R, KATO Y, BORCHARD F, COOPER H, DAWSEY S et al. The Vienna classification of gastrointestinal epithelial neoplasia. Gut 2000; 47(2):251-255.

28. BOERIU A, BRUSNIC O, ONISOR D, PASCARENCO O, BOERIU C, DOBRU D. The usefulness of white light endoscopy, narrow band imaging and magnification for the optimization of diagnosis in Barrettt's esophagus. Acta Medica Marisiensis 2014; 60(6):244-248. 
29. FITZGERALD RD, DI PIETRO M, RAGAUNATH K, ANG Y, KANG JY, WATSON P et al. British Society of Gastroenterology guidelines on the diagnosis and management of Barrett's esophagus. Gut 2014; 63(1):7-42

30. ENDO T, AWAKAWA T, TAKAHASHI H, ITOH F, YAMASHITA K, SASAKI S et al. Classification of Barrett's epithelium by magnifying endoscopy. Gastointest Endosc 2002; 55(6):641-7.

31. TANTAU M., LASZLO M, TANTA A. Barrett's Esophagus-state of the art. Chirurgia (Bucur) 2018; 113:46-60.

32. BAZIN C, BENEZECH A, ALESSANDRINI M, GRIMAUD JC, VITTON V. Esophageal motor disorders are a strong independent associated factor of Barret's esophagus. J Neurogastroent Motil 2018; 30; 24(2):216-225.

Received March $23^{\text {rd }} 2019$ 